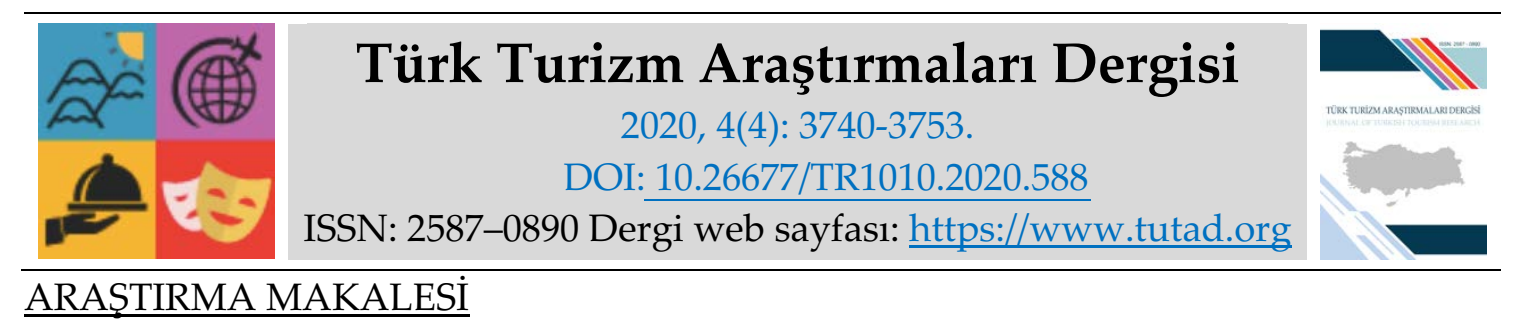

\title{
Hijyen Restoranlar İçin Hala Bir Şikâyet Nedeni mi? Mersin'deki Alakart Restoranlara Yönelik Çevrimiçi Müşteri Şikâyetleri Üzerinden Bir Araştırma
}

Dr. Öğr. Üyesi Ozan GÜlER, Mersin Üniversitesi, Turizm Fakültesi, Mersin, e-posta: ozanguler@mersin.edu.tr ORCID: https://orcid.org/0000-0002-0062-3983

Fatma YAYLA, Yüksek Lisans Öğrencisi, Mersin Üniversitesi, Sosyal Bilimler Enstitüsü, Mersin, e-posta: ftmyyla@gmail.com

ORCID: https://orcid.org/0000-0002-7470-9798

\section{Öz}

Restoran işletmeleri için hijyen her zaman için önemli konulardan birisi olmuştur. Bununla birlikte son 6 aydır dünya genelinde yaşanan Koronavirüs (Covid-19) salgını nedeniyle çok daha önemli bir konu haline gelmiştir. Hizmet kalitesinin önemli faktörlerinden birisi olan hijyen konusu gerek şikayet yönetimi gerekse dışarıda yeme davranışları konusunda turizm alanyazınında sıklıkla ele alınan bir konudur. Çoğunlukla hizmetin tüm unsurlarıyla birlikte ele alınan bu konu, bu araştırma kapsamında tek başına ele alınmıştır. Tripadvisor.com internet sitesinde yer alan Mersin'deki alakart restoranlara yönelik çevrimiçi hijyen şikayetleri üzerinden veri toplanmıştır. Ocak 2013 - Haziran 2020 arasında, Tripadvisor.com'da Mersin'de bulunan 22 Alakart restorana yönelik yapılan 1600 olumlu ve olumsuz yorum içerisinden, hijyen sorununu işaret eden 106 kişiden 141 yorum elde edilmiştir. Veriler, nitel araştırma yöntemlerinden betimsel analiz tekniği ile analiz edilmiştir. Elde edilen bulgular, hijyene yönelik müşteri şikayetlerinin mikrobiyolojik hijyen ve ortak kullanım alanlarına yönelik hijyen boyutlarında yoğunlaştı̆̆ını göstermektedir. En sık karşılaşılan şikâyet unsurları; “taze olmayan ürün kullanımı", "kirli mekân”, "kirli eşyalar”, "kirli lavabo ve tuvalet" ve "servis ekipmanlarının kirliliği" şeklindedir. Ek olarak sunum ve personelden kaynaklı hijyen sorunları da ciddiye alınacak derecede yüksektir. Bu bulgular alanyazındaki önceki araştırma bulgularıyla benzeşmekle beraber, alakart restoranlar örnekleminde mikrobiyolojik hijyen yani gıda hazırlama sürecine yönelik hijyene dair sorunların daha baskın olduğu sonucunu ortaya koymaktadır. Araştırma sonuçları restoran yöneticilerinin hijyeni, hizmet sürecinin tüm aşamaları için mutlak bir zorunluluk olarak görmeleri gerektiğini de ortaya koymaktadır.

Anahtar Kelimeler: Hizmet Başarısızlıkları, Müşteri Şikâyetleri, Restoran Hijyen Şikâyetleri, Tripadvisor.com

Makale Gönderme Tarihi: 18.06 .2020

Makale Kabul Tarihi: 05.10.2020

\footnotetext{
Önerilen Atıf:

Güler, O. ve Yayla, F. (2020). Hijyen Restoranlar İçin Hala Bir Şikâyet Nedeni mi? Mersin'deki Alakart Restoranlara Yönelik Çevrimiçi Müşteri Şikâyetleri Üzerinden Bir Araştırma, Türk Turizm Araştırmaları Dergisi, 4(4): 3740-3753.

(C) 2020 Türk Turizm Araştırmaları Dergisi.
} 


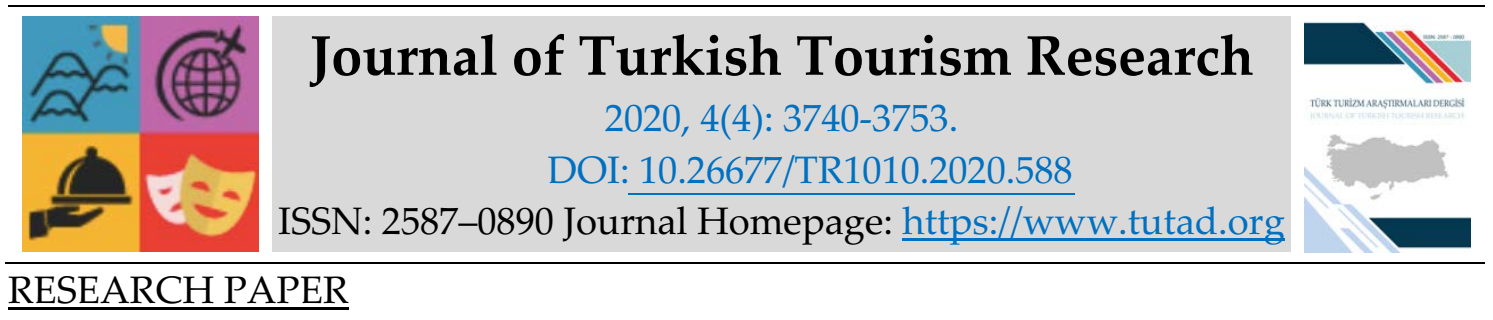

\title{
Does Hygiene Still a Reason For Complain at the Restaurants? A Research through Online Customer Complaints on the A La Carte Restaurants in Mersin
}

Assistant Prof. Dr. Ozan GÜLER, Mersin University, Faculty of Tourism, Mersin, e-mail: ozanguler@mersin.edu.tr

ORCID: https://orcid.org/0000-0002-0062-3983

Fatma YAYLA, MSc. Student, Mersin University, Social Sciences Institute, Mersin, e-mail: ftmyyla@gmail.com

ORCID: https://orcid.org/0000-0002-7470-9798

\begin{abstract}
Hygiene has always been an important issue for restaurant businesses. However, due to the Coronavirus (Covid-19) outbreak experienced worldwide for the last 6 months, it has become a much more important issue. Hygiene, which is one of the important factors of service quality, is a subject that is frequently addressed in tourism literature, both in complaint management and eating out behaviors. Hygiene issue, often handled together with all the elements of the service quality, has been single-handedly examined within the scope of this research. Data were collected upon online hygiene complaints for à la carte restaurants in Mersin through Tripadvisor.com. Among the 1600 positive and negative comments made for 22 a la carte restaurants in Mersin on Tripadvisor.com between January 2013 and June 2020, 141 comments obtained from 106 people who pointed to the hygiene problem. The data were analyzed with the descriptive analysis technique under the qualitative research methods. Findings reveal that customer complaints about hygiene intensify in microbiological hygiene and hygiene dimensions for common use areas. The most common complaints are; "non-fresh product use", "dirty place", "dirty items", "dirty sink and toilet" and "dirty service equipment". In addition, hygiene problems arising from the service process and staff are also high enough to be taken seriously. Although these findings are similar to the previous research findings in the literature, it is seen that the microbiological hygiene, that is, the problems related to the food preparation process, are more dominant in the a la carte restaurants. The outcomes of the research also show that the restaurant managers should evaluate hygiene as an absolute must for all stages of the service process.
\end{abstract}

Keywords: Service Failures, Customer Complaints, Restaurant Hygiene Complaints, Tripadvisor.com Received: 18.06 .2020

Accepted: 05.10.2020

\section{Suggested Citation:}

Güler, O. and Yayla, F. (2020). Does Hygiene Still a Reason For Complain at the Restaurants? A Research through Online Customer Complaints on the A La Carte Restaurants in Mersin, Journal of Turkish Tourism Research, 4(4): 3740-3753.

(C) 2020 Türk Turizm Araştırmaları Dergisi. 


\section{Gíriş}

Her şeyin çok hızlı değiştiği günümüzde, dışarıda yemek yeme davranışı da bu değişimden payını almaktadır. Önceleri kendi deneyimleri ve yakın çevrenin tavsiyelerine göre şekillenen restoran tercihleri artık internet ve sosyal medyanın etkisi altındadır. Internet ve sosyal medya kanalları aracılığıyla paylaşılan yemek davranışları, yeme-içmeyi insan hayatındaki bir ihtiyaçtan öte sosyal statü ölçütüne çevirmeye başlamıştır (Özdemir, 2019: 21). Akıllı telefonlardaki mobil uygulamalar ve internet üzerindeki tüketici değerlendirme siteleri sayesinde, tüketiciler hizmet almayı düşündükleri herhangi bir işletme hakkında daha önceki müşteri yorumlarına ulaşabilmektedirler (Doğan, Yücel Güngör ve Tanrısevdi, 2016: 2; Çuhadar, Özkan ve Çaylıkoca, 2017: 37). Tüketicilerin restoran tercihleri; restoranın atmosferi, personelin hizmet sunumu, yiyecek-içeceğin içeriği ve fiyat gibi belirgin değişkenlere göre şekillenir (Sulek ve Hensley, 2004: 236; Chang, Khan ve Tsai, 2012: 602; Albayrak, 2013: 27). Buradan hareketle kendi önem verdikleri kriterleri daha önceki müşteri yorumlarıyla karşılaştıran tüketiciler nihai kararlarını oluştururlar. Bir müşteri için restoranın manzarası her şeyden önemli olabilecekken, bir başka müşteri için hizmet kalitesi ve personel niteliği ön plana çıkabilir. Yukarıda sayılan temel restoran seçim kriterleri elbette kişiden kişiye değişebilir. Ancak belki de değişmeyecek olan ve fiyat dışındaki diğer unsurları da derinden etkileyebilecek öneme sahip bir değişken daha söz konusudur. Bu değişken tüketicilerin temizlik yani hijyen beklentisidir. Gerek hızlı yemek gerekse alakart restoranlar örnekleminde yapılan araştırmalar gıda güvenliği ve hijyenin restoran tercihinde çok etkili unsurlar olduğunu ortaya koymuştur (Pettijohn vd., 1997; Sienny ve Serli, 2010; Şahin, Çakıcı ve Güler, 2014; Ayaz ve Sünbül, 2018). Yüksel ve Yüksel (2002) ve Law vd., (2008) turistlerin yemek tercihleri üzerine gerçekleştirdiği araştırmalarında gıda kalitesi ve hijyenin en önemli ikinci tercih faktörü olduğunu tespit etmişlerdir. Vilnai, Yavetz ve Gilboa (2010) hizmet ortamındaki temizliğin, zevk-güven ve prestij duyguları üzerinde olumlu etki eden bir unsur olduğunu bulgulamıştır. Yani hizmet ortamının temizliğini aslında bir nevi olumlu imaj göstergesidir. $\mathrm{Bu}$ öneme karşın hijyen sorunları restoranlarda sık yaşanana hizmet başarısızlıklarından birisidir. Restoranlarda yaşayan müşteri şikâyetlerini inceleyen araştırmalar, genel restoran temizliği ve hijyeni konusunun en çok şikâyet oluşturan unsurlardan birisi olduğunu ortaya koymaktadır (Kitapçı, 2008; Olcay ve Özekici, 2015; Dalgıç, Güler ve Birdir, 2016; Unur, Erdem ve Şeker, 2017).

Yemeğin geç gelmesi, fazla pişirilmesi, kaba sunum, hatalı hesap işlemleri vb. gibi sorunlar restoran işletmelerinin doğasında vardır (Yang ve Mattila, 2012: 399). Bunların bir kısmı basit şekilde telafi edilebilirken, bir kısmı daha karmaşık telafi stratejilerini gerekli kılabilir. Ancak hijyene yönelik sorunlar bilhassa alakart hizmet veren restoranlarda yemek yiyen müşteriler açısından çok daha kritiktir ve telafi edilmesi oldukça güçtür. Doğan, Yücel Güngör ve Tanrısevdi (2016) Kuşadası'ndaki yiyecek ve içecek işletmeleri üzerindeki çalışmalarında sağllğı olumsuz yönde etkileyecek koşullarda yemek üretimi ve sunumunun telafi edilemeyecek sonuçlar doğurabileceği ifade edilmiştir. Hijyen sorunu Bitner, Booms ve Tetrault (1990) ve Bitner, Booms ve Mohr'un (1994) içinde yiyecek-içecek işletmesi müşterisi ve çalışanlarının da olduğu örneklemler üzerinde yaptığı araştırmalarda, "hizmet ulaştırma sürecine yönelik hatalar" sınıfında kategorize edilmiştir. Dolayısıyla temizlik ve hijyen anlayışının bir çok süreci kapsadığı açıkça söylenebilir. Tüketicilerin karşılanmayan hizmet beklentileri şikâyete davranışına dönüşür. Şikâyet, "müşterilerin nesnel değerlendirmelerinin duygusal tepkiler ile dile getiriliş şekli" olarak tanımlanabilir (Fornell ve Wernerfelt, 1987: 338). Kimi müşteriler şikâyetine işletme içinde çözüm aramayı seçerken, bazı müşteriler tam tersine ve hiç de istenmeyeceği üzere, şikâyetine dışarda çözüm arama, çözüm aramak yerine olumsuz deneyimleri yayma ve öç almak gibi davranışlara da yönelebilir (Yang ve Mattila, 2012: 402; Kim, Lee ve Mattila, 2014: 894). 
Büyük maddi yatırımlarla kurulan birinci sınıf restoranlar açısından bu durum hiç de istenen bir durum değildir. $\mathrm{Bu}$ nedenle bu araştırmada restoranların çözüm bulması gereken hizmet hatalarından birisi olan hijyen sorunları konusu tek başına ele alınarak, Tripadvisor.com internet sitesinde yer alan Mersin'deki alakart restoranlara yönelik çevrimiçi hijyen şikayetleri analiz edilmiştir. Alanyazında yer alan hijyen şikayetlerine yönelik araştırmalar incelendiğinde restoran işletmeleri örnekleminde çoğunlukla diğer hizmet başarısızlıkları ile birlikte ele alındığı görülmüştür (Tripp vd., 1995; Pettijohn, 1997; Heung, 2002; Baek, Ham ve Yang, 2006; Dutta, Venkatesh ve Parsa, 2007; Namkung ve Jang, 2007; Kitapçı, 2008; Liu ve Jang, 2009; Pantelidis, 2010; Zorlu, Çeken ve Kara, 2013; Şahin, Çakıcı ve Güler, 2014; Olcay ve Özekici, 2015; Dalgıç, Güler ve Birdir, 2016; Doğan, Yücel Güngör ve Tanrısevdi, 2016; Özdemir Güzel, 2017; Unur, Erdem ve Şeker, 2017; Erdem ve Yay, 2017; Kılıç, 2018; İbiş, Kızıldemir ve Çöp, 2019; Yaşar, 2019). $\mathrm{Bu}$ araştırmanın diğerlerinden ayrılan en belirgin kısmı ise sadece hijyen şikayetlerine yoğunlaşmış olmasıdır. Bu araştırma ile Mersin'de hizmet veren Alakart restoranlar örnekleminde hijyen şikayetlerin hangi sıklıkta ve hangi kategoriler bağlamında yaşandığı ortaya koyularak alanyazına ve uygulayıcılara yönelik çıtılar sunulması hedeflenmektedir.

\section{KAVRAMSAL ÇERÇEVE ve LITERATÜR TARAMASI}

Yiyecek ve içecek işletmelerinde hizmet kalitesinin belirli düzeyde karşılanması müşterilerde memnuniyet ve sadakat gibi duygular yaratılması açısından oldukça önemlidir (Karamustafa, 2018: 475; Sandıkçı, 2007: 43). Hizmet işletmelerinde hizmet başarısızlıklarının tamamen ortadan kaldırılamadığı göz önüne alındığında (Patterson, Cowley ve Prasongsukarn, 2006: 263) işletmelerin yapması gereken başlıca iş; hizmet başarısızlığı sayılabilecek durumları sistemli olarak analiz ederek, hizmet iyileştirici çözümleri etkin bir şekilde tasarlamak ve uygulamaktır (McColl-Kennedy, Daus ve Sparks, 2003: 66; Doğrul ve Yağcl, 2015: 2). Bu noktada yiyecek-içecek endüstrisinin temel unsurlarından olan restoran işletmeleri için çözülmesi gereken başlıca hizmet kalitesi unsurlarından birisi de hijyen ve sanitasyon konusudur (Unur, Erdem ve Şeker, 2017: 1366-1372; Karamustafa, 2018: 475). Kavram olarak hijyen; insan sağlığını korumak, geliştirmek ve devamlılığını sağlamak için gereken önlemler ile sağlık konularını kapsayan bir bilim dalı iken, sanitasyon; hijyen ve sağlık koşullarının oluşturulması ve devam ettirilmesi anlamında uygulamalı bir bilim dalıdır (Tayar ve Kılıç, 2014: 3-14). Hijyen, işletmeler için sağlıklı bir ortamın oluşturularak müşteri memnuniyetinin sağlanması açısından önem arz etmektedir ve her işletme hijyen açısından maksimum güvenirliğe ulaşmak zorundadır (Can, 2008; 28). Alanyazında hijyen konusu çok çeşitli sınıflandırmalarla ele alınmaktadır. Yapılan alanyazın taraması ışığında Tablo 1.'deki sınıflandırma oluşturulmuştur. Buna göre hijyen konusu, mikrobiyolojik hijyen (yiyecekiçecek hijyeni), atmosfer hijyeni, ortak kullanıma yönelik hijyen (bina hijyeni-çevresel hijyen) ve sunum ve personele yönelik hijyen şeklinde dört sınıfta ele alınabilir.

Yerli ve yabancı alanyazın incelendiğinde yiyecek-içecek işletmelerinde farklı türdeki restoranlar örnekleminde, müşterilerin hijyen beklentileri ve şikayetleri ele alınmıştır. Müşterilerin şikayetçi oldukları hijyen konusu bir çok çalışmada, hizmet kalitesinin diğer boyutlarıyla birlikte ele alınırken, sınırlı sayıda araştırma müşterilerin hijyen şikayetlerini tek bir olgu olarak ele almıştır. Dutta, Venkatesh ve Parsa (2007) Hindistan'daki restoranlarda ortaya çıan hizmet hatalarını ortaya koymak amacıyla yaptıkları araştırmalarında hijyen sorunlarının tüketilen gıdanın kendisi (\%36.8) ve genel alanların temiz olması (\%15.8) ile ilgili olduğunu ortaya koymuşlardır. Sarter ve Sarter (2012) Madagaskar'da küçük restoranlardaki hijyene yönelik çalışmasında sunulan salatalarda fekal kontamisyonların (Escherichia coli, Salmonella spp.) yüksek oranda olduğunu tespit etmişlerdir. Bu durumun işletmenin hijyenik olmayan davranışlarından kaynaklandığını ve restoranların içinde çalışan kişilerin uygun kıyafetler giymediklerini 
gözlemlemişlerdir. Zorlu, Çeken ve Kara (2013) otel işletmelerinde restoran şikâyetlerinin şikâyet davranışlarına etkisi konulu çalışmalarında, hizmet atmosferi kaynaklı şikâyette bulunma eğiliminin diğerlerine oranla en fazla olduğu görülmüştür. Restoranın ve kullanılan ekipmanların yeterince temiz olmaması en çok memnuniyetsizlik oluşturan boyutlardan birisi olarak öne çıkmıştır.

Tablo 1. Hijyen İle İlgili Özelliklere Ait Şikâyetlerin Sınıflandırılması

\begin{tabular}{|c|c|}
\hline Çalışma & Sinıflandirma \\
\hline $\begin{array}{l}\text { Mikrobiyolojik hijyen } \quad \text { (yiyecek içecek } \\
\text { hijyeni) }\end{array}$ & $\begin{array}{l}\text { Tripp vd., (1995); Yüksel ve Yüksel (2002); } \\
\text { Baek, Ham ve Yang (2006); Sienny ve Serli } \\
\text { (2010); Dutta, Venkatesh ve Parsa (2007); } \\
\text { Pettijohn(1997); Law vd., (2008) }\end{array}$ \\
\hline Atmosfer hijyeni & $\begin{array}{l}\text { Heung (2002); İbiş, Kızıldemir ve Çöp (2019); } \\
\text { Namkung ve Jang (2007); Pantelidis (2010); } \\
\text { Şahin, Çakıcı ve Güler (2014); Doğan, Yücel } \\
\text { Güngör ve Tanrısevdi (2016); Özdemir } \\
\text { Güzel (2017); Kılıç (2018); Liu ve Jang (2009); }\end{array}$ \\
\hline $\begin{array}{l}\text { Ortak kullanıma yönelik hijyen (bina ve } \\
\text { çevresel hijyen) }\end{array}$ & $\begin{array}{l}\text { Aksoydan (2007); Unur, Erdem ve Şeker } \\
\text { (2017); Law vd., (2008) }\end{array}$ \\
\hline Sunuma ve personele yönelik hijyen & $\begin{array}{l}\text { Sienny ve Serli (2010); Aksoydan (2007) } \\
\text { Özdemir Güzel (2017); Kılıç (2018) }\end{array}$ \\
\hline
\end{tabular}

Tripadvisor.com, restoran müşterilerinin şikâyetlerine kolay ulaşabilme olanağ 1 nedeniyle araştırmacılar için önemli bir kaynak olmuştur. Bu örneklem üzerinde araştırma gerçekleştiren Dalgıç, Güler ve Birdir (2016) restoran şikâyetlerini Mersin ve Hatay bağlamında karşılaştırdıkları araştırmalarında, çevresel temizlik sorununun her iki ilde de faaliyet gösteren işletmeler açısından en çok vurgulanan müşteri şikâyeti olduğunu belirtmişlerdir. Kötü koku sorununun Hatay'da, kirli ve kötü giyimli çalışanlar sorununun ise Mersin'de baskın bir şikâyet unsuru olduğu ortaya koyulmuştur. Özdemir Güzel (2017) İstanbul'da yaptığı Tripadvisor örneği çalışmasında ambiyans kalitesi bağlamında temizlik ve hijyen şikayetlerini ele almıştır. En sık gözlenen hijyen şikayetleri; mekâna ait tuvalet, masa ve ortak alanlara yönelik kirlilik olmuştur. Erdem ve Yay (2017) Tripadvisor'daki müşteri şikâyetlerini Antalya örnekleminde değerlendirdiği araştırmalarında personelin kişisel hijyen sorununun ön plana çıktı̆̆ını belirtmişlerdir. Son olarak Yaşar (2019) Kastamonu'da örnekleminde gerçekleştirdiği araştırmasında hizmet ortamıyla ilgili bulgularında restoranların ortak kullanım alanlarının kirliliği ve havasız olması şeklinde hijyen sorunları olduğunu raporlamıştır. Alanyazındaki çalışmalar özetlenecek olursa hijyen şikayetlerinin genellikle çoklu hizmet şikayetleri bağlamında ele alındığı görülmektedir. Yukarıda özetlenen bu çalışmaların bulguladığı ortak hijyen şikayetleri ise; gıdanın kendisine yönelik hijyen sorunları, personelin hijyen bilgisi eksikliği, personelin kişisel hijyen sorunları, ortak kullanım alanlarının kirliliği ve servis ekipmanlarının kirliliği şeklindedir. 


\section{YÖNTEM}

Araştırma nitel araştırma tasarımı ile hazırlanmıştır. Nitel araştırma; gözlem, görüşme ve doküman analizi gibi veri toplama yöntemlerinin kullanıldığı, algıların ve olayların doğal ortamda gerçekçi ve bütüncül bir biçimde ortaya konmasına yönelik bir süreç olarak tanımlanmaktadır (Yıldırım ve Şimşek, 2005; 39). Bu araştırma kapsamında Tripadvisor.com internet sayfasındaki müşteri yorumları, doküman analizi tekniğiyle toplanarak, belli kavram ve kelimelerin varlı̆̆ına göre analize dâhil edilmiştir.

\section{Kapsam}

Araştırmanın kapsamı iki açıdan ele alınmıştır. Değişkenler bağlamında kapsam müşterilerin restoranlarda deneyimledikleri hijyen sorunlarıyla sinırlı tutulmuş, servis kalitesi, atmosfer özellikleri, dekorasyon, müzik, fiyat vb. diğer konulardaki şikayetler kapsam dışında bırakılmıştır. Örneklem bağlamında kapsam ise Tripadvisor.com internet sitesinde yer alan Mersin'deki 22 alakart restoranlara yönelik yapılan olumsuz müşteri yorumlarıla sınırlı tutulmuştur. Bulgu ve sonuçların değerlendirilmesinde ve genellenmesinde bu husus dikkate alınmalıdır.

\section{Evren ve Örneklem}

Araştırmanın evreni restoran hijyen sorunlarından hareketle aslında Türkiye'de bulunan tüm alakart servis yapan restoranlardır. Ancak böylesi büyük bir evrene ulaşmak mümkün olmadığı için çalışma evreni seçimine gidilerek (Karasar, 2014: 110), evren Mersin'de faaliyet gösteren alakart restoranlar olarak belirlenmiştir. Bu evrene ulaşabilmek adına Tripadvisor.com internet sayfasındaki şikâyet yorumları incelenmiştir. İlgili internet adresinde yer alan restoran seçim kategorilerinin fazlalığından hareketle örnekleme belirleme yoluna gidilmiş ve amaçlı örnekleme yoluyla en az 20 müşteri yorumuna sahip restoranlar örneklem olarak alınmıştır. Ocak 2013 Haziran 2020 başı itibariyle Tripadvisor.com'da Mersin şehrinde yer alan 22 Alakart restorana yönelik yapılan 1600 olumlu ve olumsuz yorum içerisinden, hijyen sorununu işaret eden 106 kişiden elde edilen 141 olumsuz yorum örneklem olarak belirlenmiştir.

\section{Veri Analiz Yöntemi ve Veri Toplama Süreci}

Nitel araştırma analiz teknikleri içerik analizi ve betimleyici analiz olarak ikiye ayrılır (Yıldırım ve Şimşek, 2005; 22). Bu araştırmada betimleyici analizden faydalanılmıştır. Betimleyici analizi, içerik analizinden ayıran en belirgin özellik daha önceden belirlenmiş tema ve kodların referans alınmasıdır (Altunışık vd., 2001; 222; Yıldırım ve Şimşek, 2005; 22; Aydoğdu, Karamustafaoğlu ve Bülbül, 2017; 558-559). Veri analizi Strauss ve Corbin'in önerdiği 4 aşamalı betimsel analiz süreci ile gerçekleştirilmiştir (Yıldırım ve Şimşek, 2011; 224). Müşteri hijyen şikayetleri bağlamında 106 kişiden elde edilen 141 şikayet yorumuna yönelik ana temalar Tayar ve Kılıç'ın (2014) sinıflandırmasından hareketle; mikrobiyoloji-gıda ile ilgili şikayetler, ortak kullanıma yönelik alanlar ilgili şikayetler (çevresel ve bina), sunum ve personele yönelik hijyen ile ilgili şikayetler ve atmosfer ile ilgili şikayetler olmak üzere dört boyut şeklinde belirlenmiştir. Alt kodlar ise alan yazında daha önce gerçekleştirilen; Dutta, Venkatesh ve Parsa (2007); Zorlu, Çeken ve Kara (2013); Dalgıç, Güler ve Birdir (2016); Özdemir Güzel (2017); Erdem ve Yay (2017) ve Yaşar'ın (2019) çalışmalarından hareketle belirlenmiştir. 


\section{ARAŞTIRMANIN BULGULARI}

\section{Hijyen Kategorilerine İlişkin Genel Özellikler}

Gerçekleştirilen içerik analizi sonucunda ortaya çıkan hijyen şikayetleri 4 boyutta toplanmıştır. Bu boyutlar mikrobiyolojiyle ilgili şikayetler, ortak kullanıma yönelik hijyen ile ilgili şikayetler, sunum ve personele yönelik hijyen ile ilgili şikayetler ve atmosfer hijyeni ile ilgili şikayetler şeklinde sıralanmaktadır. Tablo 2.'de paylaşılan betimleyici istatistiklerden hareketle, 141 yorum neticesinde en fazla gözlenen hijyen sorununun \%36,88 ile mikrobiyolojiye yönelik hijyen sorunu olduğu ve bunu takiben \%34,04 ile ortak kullanıma yönelik hijyen sorununun geldiği görülmektedir. Sunum ve personel yönelik hizmetlerin hijyenikliğine yönelik şikâyet oranı $\% 19,86$ iken en az hijyen şikayeti \%9,22 ile atmosfere yönelik hijyen sorunları olmuştur. Detaylı betimleyici istatistikler Tablo 2' de gösterilmektedir.

Tablo2. Hijyen Şikâyetlerine İlişkin Betimleyici İstatistikler

\begin{tabular}{|c|c|c|c|c|c|c|}
\hline $\begin{array}{l}\text { HİJYEN } \\
\text { FAKTÖRLERİ }\end{array}$ & KULLANILAN İFADELER & $\Sigma \mathbf{i}$ & $\begin{array}{l}\Sigma \mathrm{i} \\
(\mathbf{1 4 1})\end{array}$ & \begin{tabular}{|l|} 
Grup \\
İçinde \\
$\%$ \\
\end{tabular} & $\begin{array}{l}\text { Toplam } \\
\text { İçinde } \\
\% \\
\end{array}$ & \begin{tabular}{|l|} 
Boyut \\
Olara \\
$\mathbf{k} \%$ \\
\end{tabular} \\
\hline \multirow{3}{*}{$\begin{array}{l}\text { (1)Mikrobiyolojik } \\
\text { Hijyen }\end{array}$} & \begin{tabular}{|lll}
$\begin{array}{l}\text { (1.1)Taze } \\
\text { kullanımı }\end{array}$ & \\
\end{tabular} & 41 & \multirow{3}{*}{52} & 0,79 & 29,08 & \multirow{3}{*}{36,88} \\
\hline & $\begin{array}{l}\text { (1.2)Uygun şekilde pişmemiş } \\
\text { et }\end{array}$ & 9 & & 0,17 & 6,38 & \\
\hline & (1.3)İyi yıkanmamış sebze & 2 & & 0,04 & 1,42 & \\
\hline \multirow{5}{*}{$\begin{array}{l}\text { (2)Ortak Kullanıma } \\
\text { Yönelik Hijyen }\end{array}$} & (2.1)Kirli mekân & 22 & \multirow{5}{*}{48} & 0,46 & 15,60 & \multirow{5}{*}{34,04} \\
\hline & (2.2)Kirli eşya & 12 & & 0,25 & 8,51 & \\
\hline & (2.3)Kirli lavabo ve tuvalet & 10 & & 0,21 & 7,09 & \\
\hline & (2.4)Haşere & 3 & & 0,06 & 2,13 & \\
\hline & (2.5)Kirli mutfak & 1 & & 0,02 & 0,71 & \\
\hline \multirow{4}{*}{$\begin{array}{l}\text { (3)Sunum } \\
\text { Personele } \\
\text { Hijyen }\end{array}$} & \begin{tabular}{|ll}
$\begin{array}{l}\text { (3.1)Servis ekipmanlarının } \\
\text { kirliliği }\end{array}$ \\
\end{tabular} & 10 & \multirow{4}{*}{28} & 0,36 & 7,09 & \multirow{4}{*}{19,86} \\
\hline & (3.2) Sunuma yönelik kirlilik & 8 & & 0,29 & 5,67 & \\
\hline & \begin{tabular}{|ll} 
(3.3)Personel hijyenine \\
yönelik sorunlar
\end{tabular} & 6 & & 0,21 & 4,26 & \\
\hline & \begin{tabular}{|l}
$\begin{array}{l}\text { (3.4)Kişisel hijyen } \\
\text { eksikliği }\end{array}$ \\
\end{tabular} & 4 & & 0,14 & 2,84 & \\
\hline \multirow{2}{*}{ (4)Atmosfer Hijyeni } & (4.1)Sigara dumanı & 8 & \multirow{2}{*}{13} & 0,62 & 5,67 & \multirow[b]{2}{*}{9,22} \\
\hline & (4.2)Ortamın ferah olmaması & 5 & & 0,38 & 3,55 & \\
\hline
\end{tabular}

\section{Mikrobiyolojik Hijyen İle İlgili Şikâyetler}

52 müşteri şikâyetinden oluşan bu boyut, "taze olmayan ürün kullanımı", "uygun şeklide pişmemiş et", "iyi yıkanmamış sebze" gibi maddelerden oluşmaktadır. Bu şikâyet boyutu içerisinden fazla şikâyet \%79 ile "taze olmayan ürün kullanımı" için yapılmıştır. Bu şikâyet aynı zamanda tüm şikâyet türleri arasında da \%29,08 ile en fazla şikâyetçi olunan sorun olarak ifade edilmiştir. Bu şikâyet grubunda ikinci sırada en fazla şikâyet alan durum \%17 ile "uygun şekilde pişmemiş et olmuş iken iyi yıkanmamış sebze şikâyeti sadece 2 müşteri yorumunda görülmüsştür. Bu boyuta ilişkin şikâyetlere daha detaylı baktığımızda "buzu çözülmemiş yemek", "taze 
olmayan balık", "bayat ekmek", "bekletilmiş salata”, "klor kokulu şırdan”, “bozulmuş şalgam”, "bozulmuş meze", "bozulmuş kahvaltılıklar", "yıkanmamış sebze" ve "bayat çay" gibi mikrobiyolojik hijyen şikâyeti oluşturan sorunların yaşandığı görülmektedir. Müşteri yorumlarında yer alan mikrobiyolojik hijyen boyutuna ilişkin bazı şikâyetler şu şekildedir;

(K1)...Temizlik sıfır. Garsonlar yetişemiyor. Lavabolar rezalet. İçli köfte geldi içinin buzu çözülmemiş geri gönderdik. Siparişleri garsonlar yoğunluktan dolayı unutuyor. Daha ne diyeyim. Bir daha gitmem. İnsan parasiyla ancak bu kadar rezil olur...

Başka bir müşteri ise ürünün uygun şekilde pişmemiş et yönünden çok kötü olduğunu şu şekilde ifade etmiştir;

(K65)...Maalesef eskiden daha lezzetliydi. Uzun süredir gitmiyorduk. Kadınbudu köfte eti çok yağlı ve siniri damarı ayrılmamış ağzımıza geliyordu. İskender aldık eti pişmemiş tadı lezzetli değildi. Tam bir hüsran oldu. Bir daha gitmeyi düşünmem...

\section{Ortak Kullanıma Yönelik Hijyen İle İlgili Şikâyetler}

48 müşteri şikayetinden oluşan "ortak kullanıma yönelik hijyen sorunları" boyutu, restoranın çevresel hijyeni ve bina hijyeninden kaynaklanan sorunların yer aldığı şikayetlerden oluşmaktadır. Bu boyut "kirli mekân", "kirli eşya", "kirli lavabo ve tuvalet", "haşere" ve "kirli mutfak" maddelerinden oluşmaktadır. Bu grup içerisinde yer alan "kirli mekân" şikâyeti \%46 ile en yüksek şikâyet oranına sahipken, tüm şikâyet türleri içerisinde ise $\% 15,60$ ile ikinci sırada yer almaktadır. Bu şikâyeti takiben "kirli eşya" (\%25) ve "kirli lavabo ve tuvalet" (\%21) şikâyetleri gelmektedir. Bu iki şikâyet aynı zamanda tüm şikâyetler arasında en fazla şikâyet edilen üçüncü ve dördüncü şikâyetlerdir. Haşerelerin varlığı ve mutfağın kirliliğine yönelik şikâyetler ise oldukça azdır. Yapılan hijyen şikayetlerinde bir müşteri genel işletmenin bakımsız ve kirli olmasını şu şekilde ifade etmiştir;

(K100)... Her şeyden önce kadınların da çalıştı̆̆ı bir mekânın bu kadar pis ve hijyenden uzak olması akil alacak gibi değil. Ciğer yemek için gittik ancak pişman olduk. Tatsı tuzsuz vasatin bile altında olan iki porsiyon ciğere ve mezelere 50 TL hesap ödedik ve açıkçası masaya gelenleri tuvaleti, mutfă̆ı görünce gönül rahatlı̆̆ıyla yiyemedik. Mersin'de genel olarak tantuniciler ve ciğerciler çok pis yerler belediye bu mekânları daha sık ve ciddi bir denetime tabi tutmalı resmen halk sağlığıyla oynuyorlar...

Kirli eşya boyutu; kirli masa, kirli cam, kirli masa örtüsü, kirli koltuk şikâyetlerinden oluşmaktadır. Kirli eşya boyutunda bir müşteri şu şikâyette bulunmuştur;

(K2)...Yemekler aman aman güzel değil.... Orta kalite..... Garsonlar saygısız.... Ortam kirli... Çöpler masaların yanında , masalar kirli... Çalışanlar sizleri hiç memnun etme zahmetine girmiyor...

Kirli lavabo ve tuvaletler boyutunda ise bir müşteri şu şekilde şikâyetini ifade etmiştir;

(K84)...Böyle iş yapan bir mekânın bir tane wo görevlisi olmaması kadar rezil bir durum olamaz... Yemekten önce veya sonra sakın lavaboya gitmeyin... Yemek yiyemezsiniz!!! Veya yediğinize pişman olursunuz...

\section{Sunum ve Personele Yönelik Hijyen İle İlgili Şikâyetler}

Sunum ve personele yönelik hijyen şikayetleri, "servis ekipmanlarının kirliliği", "sunuma yönelik kirlilik", "personel hijyenine yönelik sorunlar" ve "kişisel hijyen bilgi eksikliği" şikayetlerinin yer aldığı toplam 28 şikayetten oluşmaktadır. Bu grup içerisinde en fazla şikâyet alan sorun \%36 ile "servis ekipmanlarının kirli olması" iken bu sorun aynı zamanda tüm 
şikâyetler arasında "kirli lavabo ve tuvalet" şikâyetiyle beraber dördüncülügü paylaşmaktadır. Bu şikayetin akabinde \%29 ile "sunuma yönelik kirlilik, \%21 ile personelin kişisel hijyen eksikliği ve \%14 ile kişisel hijyen bilgisi eksikliği gelmektedir. İlgili şikayetleri detaylı şekilde ele aldığımızda "kirli kahvaltılık", "kirli çatal, kaşık ve bıçak", "kirli baharatlık", "açık büfede gıda kirliliği", "başkasının içeceğini tamamlayıp servis etme", "yemekte kıl çıkması", "personelin kirleterek masa toplaması", "personelin el ve kıyafet hijyeni", "personelin kötü kokması" ve "personelin kişisel hijyen bilgisi" gibi sunum ve personele yönelik hijyen şikayeti boyutlarını oluşturan müşteri yorumlarıyla karşılaşılmıştır. Bu bölümde en çok vurgulanan "servis ekipmanlarının kirliliğgi" boyutundan bir müşteri hijyen şikayeti şu şekildedir;

(K61)...Sevgili Okurlarım uzun zamandır yemek yediğim yerleri ve lezzetleri sizlerle paylaşmayah çok uzun zaman oldu. Lafi fazla uzatmadan söylüyorum. Mersin'e iş ziyareti için geldi. Mersin denilince de akla kebaplar, ciğgerler, meşhur bıcı bıcı, tantunisi... Neyse bende meşhur dedikleri Ciğgerci Bahattin'e geldim. Ifftar için rezervasyonumuzu yaptık. Masamıza oturduğumuz ilk andan itibaren rezalet başladı. Çatal ve kaşıklar hijyen sıfır, pas lekeleri çatalların üzerinde hak getire. Bardaklar çok kötü hiç mi yıkamıyorsunuz. Garsona kaşı̆̆̊ değiştirir misiniz diyorum. Getirdiği kaşık aynı böyle mekân daha önce görmedim. Çay bardaklarında lekeler. Daha fazla açıklama yapmama gerek yok. Hijyen sıfir maalesef ki hayal kırıklı̆̆ yaşadım mekânda. Bunca olan şeyden sonra midem yemek yemeği kaldırmadı yediğim yemekten bir şey anlamadım. Mideniz kalktıysa kusura bakmayın. Mekân böyle Kendinize iyi bakın okurlarım. Hayırlı Ramazanlar...

Sunuma yönelik kirlilik boyutunda rahatsızlığını bir müşteri şu şekilde belirtmiştir;

(K62)...Servis rezalet eskiden çok iyiydi bozmuşlar garsonlar beceriksiz mezeler bozulmuş yemek geç geldi masayı toplarlarken her şeyi düşürdüler bir daha gelmeyeceğiz çayları kötü kimseye tavsiye etmem...

\section{Atmosfer Hijyeni İle İlgili Şikâyetler}

Son boyut olan atmosfer hijyeni ile ilgili elde edilen 15 şikâyet incelendiğinde ilk sırayı \%62 ile "sigara dumanı" şikâyetinin aldığı, ardından ise \%38 ile "ortamın ferah olmaması" şikâyetinin geldiği görülmektedir. İlgili şikâyetleri detaylı şekilde ele aldığımızda "dekorun boğucu olması", "klimanın yetersiz olması veya açılmaması", "yemek kokuları" ve "atmosferin ferah olmaması" gibi şikâyetler ile karşılaşılmıştır. Atmosfer hijyeni şikâyeti boyutunda en çok vurgulanan "sigara dumanı" maddesiyle ilgili yapılan bir müşteri şikâyeti şu şekildedir;

(K55)...Çocuğunuzla gitmeyin, giderseniz de açık havanın keyfinden mahrum kalırsınız çünkü yoğun sigaradan dolayı içerde oturmak zorunda kalırsınız; neden sigara içmeyen insanları düşünmezler anlamam; çocukları içeri hapsetmeyin...

\section{SONUÇ ve TARTIŞMA}

Yiyecek-içecek işletmelerinde müşteri şikâyetlerinin doğru analiz edilmesi ve şikâyetlerin hangi konulardan kaynaklandığının belirlenmesi başlı başına önemli bir konudur. Daha önce yapılan çalışmalarda müşteri şikayeti bağlamında araştırmalar yapılmış olup içerisinde hijyen şikayetinin bir boyut olarak hep ele alındığı bilinmektedir. Bu bağlamda Mersin şehrinde faaliyet gösteren yiyecek-içecek işletmelerinin yalnızca hijyen şikayetlerini belirlemeye yönelik yapılan bu çalışmada, diğer çalışmalarla bazı hijyen boyutlarında benzerlik ve farlılıkların olduğu gözlemlenmiştir.

Araştırma sonuçlarının alt şikâyet temaları bağlamında, Unur, Erdem ve Şeker (2017), Erdem ve Yay (2017), Yüksel ve Yüksel (2002) ve Özdemir Güzel'in (2017) çalışmalarıyla benzerlik 
gösterdiği görülmüştür. Unur, Erdem ve Şeker (2017) çalışmalarındaki şikayet unsurlarında "temizlik ve hijyen", "dekorasyon", "gürültü" ve "koku" gibi faktörleri oluşturan "ambiyansla" ilgili unsurlar en az şikayet unsurları olarak görülmüştür. Bu çalışma bulgularında da "atmosfer hijyeni" boyutunun diğer hijyen boyutlarına göre en az şikayet sebebi olduğu görülmektedir. Erdem ve Yay (2017) çalışmasında şikayetler bağlamında en çok şikayet unsurlardan birisi olan yiyecek-içecekle ilgili şikayetlerde "yemeğin uygun pişirilmemesini" en fazla şikayet edilen hijyen şikayet faktörü olarak tespit edilmiştir. Bu çalışmada da yemeğin uygun pişirilmeme unsuru "mikrobiyolojik hijyen" boyutu içerisinde en fazla hijyen şikayeti olarak bulgulanmıştır. Ek olarak Erdem ve Yay (2017) "personelin kişisel hijyeni" şikâyetini en az şikâyet edilen faktör olarak ifade ederken bu çalışmada da ilgili şikâyet unsuru çok baskın bir şikâyet türü olarak ortaya çıkmamıştır. Yüksel ve Yüksel (2002) turistlerin yemek tercihinde "ürün kalitesi" ve "hijyen" konusunu en önemli boyutlardan birisi olarak bulgulamıştır. Benzer şekilde bu araştırmada da ürün kalitesine yönelik şikayetleri içeren "mikrobiyolojik hijyen" şikayetleri en fazla gözlenen hijyen sorunu olarak ortaya çıkmıştır. Benzer şekilde yazarlar "atmosfer" ve "sigara" unsurlarının çok önemli unsurlar olmadığını raporlarken, bu araştırma sonucu da ilgili sorunlara yönelik şikâyetlerin az olduğunu göstermektedir. Özdemir Güzel (2017) çalışmasında "ambiyans" boyutunda özellikle mekâna ait "kirlilik" müşteri yorumlarında en çok geçen kod olduğunu belirtmiştir. Benzer şekilde bu araştırmada da "kirli mekân şikâyeti en fazla şikâyet alan ikinci neden olarak bulgulanmıştır. Bu araştırmanın bulguları bazı araştırmaların bulgularıyla ise çeşitli açılardan farklılıklar göstermektedir. Taştan ve Kızılcık (2017) ve Erol, Örgün ve Keskin (2019) yiyecek içecek işletmeleri örnekleminde gerçekleştirdikleri araştırmalarında hijyenin önemli bir şikâyet unsuru olmadığı sonucuna ulaşmıştır. Diğer yandan ise Temiztürk ve Akbaba (2018) ve Yaşar (2019) atmosfere yönelik hijyeni en yüksek hijyen sorunu olarak bulgulamışlarken, bu araştırma için atmosfere yönelik hijyen en az şikayet edilen sorun olarak bulgulanmıştır.

Restoranlardaki hijyen sorunlarını araştıran bu çalışmanın alanyazına yönelik çıktıları olduğu gibi restoran işletmesi yöneticileri ve çalışanlarına yönelik çıktıları da mevcuttur. Her şeyin kusursuz gittiği bir servis, dikkat edilmeyen bir hijyen eksikliği nedeniyle istenmedik şekilde sonuçlanabilir. Bilhassa Koronavirüs salgını sonrasında "yeni normal" olarak adlandırılan yaşamımızda, hijyenin yiyecek ve içecek işletmelerinin hem hizmet kalitesi hem de imajları açısından kritik bir öneme sahip olduğu söylenebilir. Araştırma bulgularına göre Mersin'deki alakart restoranlar için en sık karşılaşılan hijyen şikayeti olarak "mikrobiyolojik hijyen" boyutu ortaya çıkmıştır. Dondurulmuş ürünlerin sıcak ortamda çözdürülmesi, besinlerin açıkta bırakılmaması, uygun sıcaklıkta pişirilmesi, taze ürünlerin kullanılması işletmelere önerilmelidir. Bu durumlar dikkate alınmadığında bakteriyel üreme, havadaki bakterilerin besinlere bulaşması gibi mikrobiyolojik boyutlarda tehlikeli durumlara sebep olabilir (Bulduk ve Bulduk, 2018; 72). Benzer şekilde "ortak kullanıma yönelik hijyen" boyutundaki "kirlilik" unsurundan gelen enfeksiyon; "sunum ve personele yönelik hijyen" boyutundan kaynaklı mikroorganizma ve enfeksiyon ve "atmosfer hijyeni" boyutundan kaynaklı patojen mikroorganizma yayma gibi tehlikeli durumlar ortaya çıabilir (Bulduk ve Bulduk, 2018; 73-74). Sonuç olarak işletme yöneticilerine hijyen şikayetlerini en aza indirme konusunda şu somut öneriler getirilebilir;

- Müşterinin restorana girişinden ayrilışına kadar ki tüm süreçler için hijyen ve sanitasyon kurallarının eksiksiz uygulanması gerekir.

- Gıdaların hijyenikliği konusundaki şikâyetlerin azaltılması için, çalışanlara uygulamaya yönelik eğitimler verilmesi gerekir.

- Ortak kullanım alanlarının daha programlı bir şekilde ve sadece temizlikten sorumlu personeller tarafından temizlenmesi gerekir. Bir kominin bir yandan servise yardımcı olup, diğer yandan paspas çekmesi profesyonel bir imaj çizmeyecektir. 
- Mutfak ve servis personelinin hem kişisel hijyeni hem de servis hijyenleriyle ilgili şikâyetlerin azaltılması için kontrol mekanizmasının daha sıkı olması gerekir. Çalışanlarının kıyafetleri, el-yüz bakımları ve temizlik davranışları sürekli olarak kontrol edilmelidir.

- Sigara içilmeme yasağının müşteri kaçırmama kaygısıyla delinmesinin başka müşterilerin kaçması anlamına geldiği anlaşılmalıdır.

- Sigara içenler ile içmeyenlerin aynı restoran içerisinde sadece araya mesafe koyularak ayrılmasının sigara dumanının tüm restorana sinmesini engellemediği ortadadır. Bu noktada duman perdesi ve harici bir havalandırma sistemi ile sigara dumanı restorandan tamamen dışarıya atılmalıdır.

\section{KAYNAKÇA}

Aksoydan, E. (2007). Hygiene Factors Influencing Customers' Choice of Dining-Out Units: Findings from a Study of University Academic Staff, Journal of Food Safety, 27, 300-316.

Albayrak, A. (2013). Restoran İşletmelerinde Müşteri Şikâyetleri ve Şikâyete İlişkin Davranışlar. Paradoks Ekonomi, Sosyoloji ve Politika Dergisi, 9(2), 27-51.

Altunışık, R., Coşkun, R., Yıldırım, E. ve Bayraktaroğlu, S. (2001). Sosyal Bilimlerde Araştırma Yöntemleri, SPSS Uygulamal. Adapazarı: Sakarya Kitabevi.

Ayaz, N. ve Sünbül, K. (2018). Restoran Müşterilerinin Beklentileri ve Gıda Güvenliğine Yönelik Tepkileri Üzerine Bir Nitel Araştırma, Journal of Tourism and Gastronomy Studies, 6(1), 164-181.

Aydoğdu, Ü. R., Karamustafaoğlu, O. ve Bülbül, M. Ş. (2017). Akademik Araştırmalarda Araştırma Yöntemleri ile Örneklem İlişkisi: Doğrulayıcı Doküman Analizi Örneği, Dicle Üniversitesi Ziya Gökalp Eğitim Fakültesi Dergisi, 30, 556-565.

Baek, S. H., Ham, S. and Yang, I. S. (2006). A Cross-Cultural Comparison of Fast Food Restaurant Selection Criteria Between Korean and FilipinoCollege Students, International Journal of Hospitality Management, 25(4), 683-698.

Bitner, M. J., Booms, B. H. and Mohr, L. A. (1994). Critical Service Encounters: The Employee's Viewpoint, The Journal of Marketing, 58(4), 95-106.

Bitner, M. J., Booms, B. H. and Tetreault, M. S. (1990). The service encounter: diagnosing favorable and unfavorable incidents, The Journal of Marketing, 54(1), 71-84.

Bulduk, S. ve Bulduk, E. Ö. (2018). Gıda ve Personel Hijyeni. Ankara: Detay Yayıncılık.

Can, S. (2008). Küçük Ölçekli Otel İşletmelerinin Mutfak Departmanlarında Çalı̧̧an Personelin Hijyen ve Sanitasyon Alışkanlıkları (Erdek Yöresinde Bir Uygulama) (Yayınlanmamıı̧ Yüksek Lisans Tezi), Balıkesir Üniversitesi Sosyal Bilimler Enstitüsü, Balıkesir.

Chang, J., Khan, M. A. and Tsai, C. T. S. (2012). Dining Occasions, Service Failures and Customer Complaint Behaviours: an Empirical Assessment, International Journal of Tourism Research, 14(6), 601-615.

Çuhadar, M., Özkan, A. ve Çaylıkoca, A. (2017). Yiyecek İçecek İşletmelerine Yönelik Çevrimiçi Müşteri Değerlendirmelerinin İncelenmesi: Isparta İli Örneği, Journal of Suleyman Demirel University Institute of Social Sciences, 29(4), 33-48.

Dalgıç, A., Güler, O. ve Birdir, K. (2016). Tripadvisor.com'da Yer Alan Restoran Şikâyetlerinin Analizi: Mersin ve Hatay'da Yöresel Yiyecek Sunan Restoranlara Yönelik Bir Araştırma, Journal of Tourism and Gastronomy Studies, 4/Special Issue 1, 153-173. 
Doğan, S., Yücel Güngör, M. ve Tanrısevdi, A. (2016). Çevrimiçi Tüketici Yorumlarının İçerik Analizi Yoluyla İncelenmesi: Kuşadası'ndaki Yiyecek ve İçecek İşletmeleri Üzerinde Bir Araştırma, Uluslararası Hakemli Ekonomi Yönetimi Araştırmaları Dergisi, 9, 1-22.

Doğrul, Ü. ve Yağcl, M. İ. (2015). Hakkaniyet Teorisi Çerçevesinde Tüketicilerin Hizmet Telafilerini Değerlendirme Süreci: Kavramsal Bir İnceleme, Çă̆g Üniversitesi Sosyal Bilimler Enstitüsü Dergisi, 12(2), 1-22.

Dutta, K., Venkatesh, U. and Parsa, H. G. (2007). Service Failure and Recovery Strategies in the Restaurant Sector, International Journal of Contemporary Hospitality Management, 19(5), 351-363.

Erdem, Ö. ve Yay, Ö. (2017). Tripadvisor'daki Müşteri Şikâyetlerinin Değerlendirilmesi: Antalya Örneği, Journal of Tourism and Gastronomy Studies, 5(4), 227-249.

Erol, G., Örgün, E. ve Keskin, E. (2019). Sosyal Medyada Restoran İmajı: Kapadokya Örneği, Journal of Tourism and Gastronomy Studies, 7(2), 3290-3302.

Fornell, C. and Wernerfelt, B. (1987). Defensive Marketing Strategy by Customer Complaint Management: ATheoretical Analysis, Journal of Marketing Research, 24(4), 337-346.

Heung, V. C. (2002). American Theme Restaurants: A Study of Consumer's Perceptions of the Important Attributes in Restaurant Selection, International Journal of Hospitality Management, 25(4), 683-698

İbiş, S., Kızıldemir, Ö. ve Çöp, S. (2019). İstanbul'daki Çin Restoranlarına Yönelik Yapılan Yorumların ve E-Şikâyetlerin Değerlendirilmesi, Journal of Tourism and Gastronomy Studies, 7(1), 505-521.

Josiam, B. M. and Monteiro, P. A. (2004). Tandoori Tastes: Perceptions of Indian Restaurants in America, International Journal of Contemporary Hospitality Management, 16(1), 18-26.

Karamustafa, K. (2018). Yiyecek ve İçecek Yönetimi. Ankara: Detay Yayıncılık.

Karasar, N. (2014). Bilimsel Araştırma Yöntemi. Ankara: Nobel Yayın Dağıtım.

Kılıç, T. M. (2018). Fast Food Restoran İşletmelerinde Müşteri Şikâyetleri ve Şikâyetlere İlişkin Davranışlar: Eskişehir İli'nde Bir Uygulama (Yayınlanmamış Yüksek Lisans Tezi), Uludağ Üniversitesi Fen Bilimleri Enstitüsü, Bursa.

Kim, M. G., Lee, C. H. and Mattila, A. S. (2014). Determinants of Customer Complaint Behavior in a Restaurant Context: The Role of Culture, Price Level and Customer Loyalty, Journal of Hospitality Marketing \& Management, 23(8), 885-906.

Kitapçı, O. (2008). Restoran Hizmetlerinde Müşteri Sikâyet Davranışları: Sivas İlinde Bir Uygulama. Erciyes Üniversitesi İktisadi ve İdari Bilimler Fakültesi Dergisi,31, 111-120.

Kozak, M. (2018). Bilimsel Araştırma: Tasarım, Yazım ve Yayım Teknikleri. Ankara: Detay Yayıncılık.

Law, R., To, T. and Goh, C. (2008). How Do Mainland Chinese Travelers Choose Restaurants in Hong Kong?: An Exploratory Study of Individual Visit Scheme Travelers and Packaged Travelers, International Journal of Hospitality Management, 27(3), 346-354.

Liu, Y. and Jang, S.S. (2009). Perceptions of Chinese Restaurants in the U.S.: What Affects Customer Satisfaction and Behavioral Intentions?, International Journal of Hospitality Management 28(3),338-348.

McColl-Kennedy, J. R., Daus, C. S. and Sparks, B. A. (2003). The Role of Gender in Reactions to Service Failure and Recovery, Journal of Service Research, 6(1), 66-82. 
Namkung, Y. and Jang, S. (2008). Are Highly Satisfied Restaurant Customers Really Different? A Quality Perception Perspective, International Journal of Contemptional Hospitality Management, 20(2), 142-155.

Olcay, A. ve Özekici, Y. K. (2015). Yiyecek-İçecek İşletmelerinde Hizmet Hataları, Telafi Yöntemleri ve Müşteri Memnuniyeti İlişkisi (Gaziantep Örneği), Uluslararası Sosyal Araştırmalar Dergisi, 8(41), 1307-9581.

Özdemir Güzel, S. (2017). Birinci Sınıf Restoran İşletmelerindeki Fiziksel Çevre Unsurlarının Müşteri Yorumları Açısından Değerlendirilmesi: Tripadvisor Örneği, Akademik Sosyal Araştırmalar Dergisi, 5(62),534-542.

Özdemir, S. (2019). Sosyal Medyada Yemek Kültürüne Bakış: Instagram Örneği, Anadolu Akademi Sosyal Bilimler Dergisi, 1(2), 21-32.

Pantelidis, I. S. (2010). Electronic Meal Experience: A Content Analysis of Online Restaurant Comments, Cornell Hospitality Quarterly, 51(4), 483-491.

Patterson, P. G., Cowley, E. and Prasongsukarn, K. (2006). Service Failure Recovery: The Moderating Impact of Individual-Level Cultural Value Orientation on Perceptions of Justice, International Journal of Research in Marketing, 23(3), 263-277.

Pettijohn, L. S., Pettijohn, C. E. and Luke, R. H. (1997). An Evaluationof Fast Food Restaurant Satisfaction: Determinants, Competitive Comparisons and Impact on Future Patronage, Journal of Restaurant \& Foodservice Marketing, 2(3), 3-20.

Sandıkçı, M. (2007). Müşteri Memnuniyeti Ölçülmesi ve Sandıklı Hüdai Kaplıcası'nda Bir Alan Araştırması, Afyon Kocatepe Üniversitesi İktisadi ve İdari Bilimler Dergisi, 9(2),39-53.

Sarter, G. and Sarter, S. (2012). Promoting a Culture of Food Safety to Improve Hygiene in Small Restaurants in Madagascar, Food Control, 25(1), 165-171.

Sienny, T. and Serli, W. (2010). The Concern and Awareness of Consumers and Food Service Operators Towards Food Safety and Food Hygiene in Small and Medium Restaurants in Surabaya, Indonesia, International Food Research Journal, 17, 641-650.

Sulek, J. M. and Hensley, R. L. (2004). The Relative Importance of Food, Atmosphere and Fairness of Wait the Case of a Full-Service Restaurant, Cornell Hotel and Restaurant Administration Quarterly, $45(3), 235-247$.

Şahin, A., Çakıcı, A. ve Güler, O. (2014). Tüketicilerin Masa Servisi Yapan Restoranlarda Önem Verdiğ Hususların Şikâyet Davranışı Eğilimlerine Etkisi. 15. Ulusal Turizm Kongresi, 683-700, Ankara.

Taştan, H. ve Kızılcık, O. (2017). Kahramanmaraş'ta Bulunan Yiyecek İçecek İşletmelerine Yönelik Tripadvisor.com'da Paylaşılan Şikâyetlerin Sınıflandırılması, Çukurova Üniversitesi Sosyal Bilimler Enstitüsü Dergisi, 26(1), 270-284.

Tayar, M. ve Kılıç, V. (2014). Gıda Endüstrisinde Hijyen ve Sanitasyon. Bursa: DoraYayıncılık.

Temiztürk, S. ve Akbaba, A. (2018). Bir Yavaş Şehir Olan Seferihisar'daki Restoranlarla İlgili Müşterilerin Sosyal Medyadaki Yorumlarının Analizine Yönelik Bir Çalışma, International Journal of Contemporary Tourism Research, 1, 78-94.

Tripp, C., Greathouse, K. R., Shanklin, C. W. and Gregoire, M. B. (1995). Factors Influencing Restaurant Selection by Travelers Who Stop at Visitor Information Centers, Journal of Travel $\mathcal{E}$ Tourism Marketing, 4(2), 41-50. 
Unur, K., Erdem, A. ve Şeker, F. (2017). Adana İlinde Bulunan Restoranlara Yönelik İnternet Üzerinden Yapılan Tüketici Şikâyetlerinin İncelenmesi: Tripadvisor.com Örneği, Futourism Congress, 1366-1376, Mersin.

Vilnai-Yavetz, I. and Gilboa, S. (2010). The Effect of Servisescape Cleanliness on Customer Reactions, Services Marketing Quarterly, 31, 213-234.

Yang, W. and Mattila, A. S. (2012). The role of tie strength on consumer dissatisfaction responses. International Journal of Hospitality Management, 31(2), 399-404.

Yaşar, Z. (2019). Kastamonu'da Yöresel Yiyecek İçecek Hizmeti Sunan Restoranlara İlişkin Tüketici Şikâyetlerinin Değerlendirilmesi: Tripadvisor Örneği, Safran Kültür ve Turizm Araştırmaları Dergisi, 2(2), 241-250.

Yıldırım, A. ve Şimşek, H. (2005). Sosyal Bilimlerde Nitel Araştırma Yöntemleri. Ankara: Seçkin Yayıncilik.

Yüksel, A. ve Yüksel, F. (2002). Market Segmentation Based on Tourısts' Dining Preferences, Journal of Hospitality \& Tourism Research, 26(4), 315-331.

Zorlu, Ö., Çeken, H. ve Kara, A. M. (2013). Otel İşletmelerinde Restoran Şikâyetlerinin Şikâyet Davranışlarına Etkisi: Afyonkarahisar İli Örneği, Dokuz Eylül Üniversitesi Sosyal Bilimler Enstitüsü Dergisi, 15(3), 529-554. 